\title{
Distribution of pre-mRNA splicing factors at sites of RNA polymerase II transcription
}

\author{
Karla M. Neugebauer ${ }^{1-3}$ and Mark B. Roth $^{1}$ \\ ${ }^{1}$ Division of Basic Sciences, Fred Hutchinson Cancer Research Center, Seattle, Washington, 98109 USA; ${ }^{2}$ Gene Expression \\ Programme, European Molecular Biology Laboratory, 69117 Heidelberg, Germany
}

If pre-mRNA splicing begins during RNA synthesis, then transcriptionally active genes may be expected to contain high concentrations of pre-mRNA splicing factors. However, previous studies have localized splicing factors to a network of "speckles," which is distinct from individual sites of gene transcription where pre-mRNA is spliced. Speckles have been detected with antibodies specific for splicing snRNPs and members of the SR family of splicing factors. Here we report that dilution of these probes results in the visualization of hundreds of sites throughout the HeLa cell nucleus, the size and distribution of which are consistent with transcription units viewed with light microscopy. Importantly, these sites of highest SR protein concentration frequently coincide in three-dimensional space with active sites of RNA polymerase II transcription. A newly developed reagent specific for a single member of the SR family, SRp20, detects a subset $(\sim 20 \%)$ of these sites, suggesting the gene-specific accumulation of these splicing regulators, which have distinct functions in pre-mRNA splicing. These observations question the view that the nucleus and its functions are highly compartmentalized; instead, they support a model in which the localization of these and possibly other gene regulators is determined primarily by their function.

[Key Words: Pre-mRNA splicing; RNA polymerase II; SR proteins; nuclear organization]

Received December 6, 1996; revised version accepted March 18, 1997.

As genes are transcribed, a diverse set of proteins and ribonucleoprotein particles (RNPs) associate with the nascent RNA. The binding of particular factors is likely to determine how the transcript will be processed to mature RNA. The observation that pre-rRNA processing and pre-mRNA splicing often occur at or very near sites of RNA synthesis (Penman et al. 1966; Rosbash and Singer 1993; Mattaj 1994) leads to the prediction that the factors regulating RNA processing may be similarly concentrated. The factors involved in pre-rRNA processing have been shown to be localized to the nucleolus, the site of rDNA transcription (Carmo-Fonseca et al. 1991; Jimenez-Garcia et al. 1994; Matera et al. 1994). In contrast, factors essential for the splicing of mRNA precursors in mammalian cell nuclei have been observed in large structures, termed "speckles," which are morphologically distinct from sites of RNA polymerase II (Pol II) transcription (Fu and Maniatis 1990; Spector 1990; Wansink et al. 1993; Zhang et al. 1994). As a first step toward resolving this enigma, we have re-examined the distribution of pre-mRNA splicing factors with respect to RNA polymerase II transcription, focusing on members of the SR protein family.

${ }^{3}$ Corresponding author.

E-MAIL neugebau@embl-heidelberg.de; FAX 496221387518.
Pre-mRNA splicing takes place within the spliceosome, a multicomponent complex of small nuclear ribonucleoprotein particles (snRNPs) and a number of nonsnRNP protein factors (Moore et al. 1993). The nine SR proteins constitute a family of nuclear phosphoproteins essential for the splicing of metazoan mRNA precursors in vitro (for review, see Black 1995; Manley and Tacke 1996; Valcarcel and Green 1996). In general, SR proteins appear to act early in splicing by promoting splice site recognition and spliceosome assembly. SR proteins also play a regulatory role, because they can determine alternative splice site usage in vivo and in vitro (Fu 1993; Zahler et al. 1993a; Caceres et al. 1994). Moreover, individual SR proteins are essential for viability (Ring and Lis 1994). These observations suggest that particular SR proteins may have essential, nonoverlapping functions in the regulation of gene expression. One prediction of these data is that many if not all intron-containing pre-mRNAs should associate with at least one SR protein during their processing to mRNA. An additional question is whether particular SR proteins have distinct distributions, reflecting distinct functions in gene regulation.

Monoclonal antibodies (mAbs) have been used extensively to address cell biological questions of gene regulation, including the localization of pre-mRNA splicing 
factors. Anti-SC35, mAb 3C5, and mAb 104 react with each of the members of the SR protein family (Roth et al. 1989; Fu and Maniatis 1990; Bridge et al. 1995; see Results), and the autoimmune epitope Sm shared among core components of snRNPs is recognized by a number of mouse monoclonal lines, notably Y12 (Lerner et al. 1981; Petterson et al. 1984). Indirect immunofluorescence studies of mammalian cell nuclei place all of these antigens in a network of large nuclear objects known as speckles (Fu and Maniatis 1990; Spector 1990; Spector et al. 1991). This localization has been somewhat perplexing, because speckles were also shown to contain stable, polyadenylated RNA species distinct in their behavior from most pre-mRNAs (for review, see Fakan 1994; Mattaj 1994). When sites of transcription and splicing have been examined using fluorescence in situ hybridization techniques, genes and the highest concentrations of unspliced pre-mRNA are coincident at the light microscopic level (Zachar et al. 1993; Zhang et al. 1994); however, endogenous intron-containing pre-mRNAs are not always concentrated within speckles (Zhang et al. 1994; Xing et al. 1995). This has led to the suggestion that speckles contain the highest concentrations of splicing factors-perhaps serving as storage or assembly sitesand that lower concentrations may be present where splicing occurs (Fakan et al. 1984; Fakan 1994; Xing et al. 1995; Huang and Spector 1996). Interestingly, SR proteins and splicing snRNPs are detected at active sites of transcription on polytene and lampbrush chromosomes, which are particularly well-suited for cytological observation (Roth et al. 1989, 1991; Champlin et al. 1991; Amero et al. 1992; Kim et al. 1992; Wu et al. 1993; Bauren et al. 1996). Although splicing factors accumulate at very large and highly active viral transcription units in infected mammalian cells /cf. Jiminez-Garcia and Spector 1993; Mattaj 1994; Zhang et al. 1994; Bridge et al. 1995), it has been difficult to understand why splicing factors have not been detected in greater abundance at endogenous sites of pre-mRNA splicing in intact nuclei.

Here we present a cytological approach to understanding SR protein function in the mammalian cell nucleus. Using modified indirect immunofluorescence methods, we detect SR proteins in nuclear structures much smaller than speckles, and these smaller particles frequently coincide with sites of endogenous RNA synthesis. Moreover, a single SR protein, SRp20, is localized to a subset of these sites of transcription and SR protein localization. We discuss a model in which particular SR proteins are specifically concentrated on pre-mRNAs as a result of their relative affinities for the pre-mRNA sequences at which they function. The methods developed here present additional opportunites for studying the actions of particular regulators of gene expression at the cell biological level.

\section{Results}

We were interested in examining the distribution of splicing factors in the HeLa cell nucleus by indirect im- munofluorescence followed by high resolution optical sectioning (Hiraoka et al. 1991; Carrington et al. 1995). We noticed that the size and shape of the nuclear objects visualized with a number of mAbs were dependent on the concentration of the primary $\mathrm{mAb}$ used. Figure 1 shows an analysis of the staining pattern observed with varying concentrations of anti-SR, a mAb that recognizes all of the members of the SR protein family (Ramchatesingh et al. 1995; see also Fig. 5A, below). Threedimensional reconstruction of nuclei stained with $\sim 0.4-1 \mu \mathrm{g} / \mathrm{ml}$ of anti-SR (1:25 and 1:10 dilutions of hybridoma supernatant) revealed hundreds of apparently spherical, discrete particles distributed throughout the nucleoplasm (Fig. 1A). However, when anti-SR hybridoma supernatant was used undiluted $(-10 \mu \mathrm{g} / \mathrm{ml})$ or diluted only fivefold, much larger aggregates were detected in addition to a number of smaller particles like those described above (Fig. 1A). Unlike the small particles, the larger objects spanned many optical sections and were highly interconnected and irregularly shaped. This distribution is reminiscent of the previously reported speckled pattern of subnuclear localization observed with other $\mathrm{mAbs}$ specific for SR proteins (Fu and Maniatis 1990; Spector et al. 1991). Note that the effects of antibody dilution do not depend on the fixation method; unfixed, permeabilized cells as well as cells fixed with either acetone or formaldehyde yield similar results (data not shown; for examples, see Figs. 4, 6, and 7). Highresolution techniques are not required for visualization of the particles that can be seen easily by eye, using a $63 \times$ or $100 \times$ objective lens.

A quantitative analysis of the particles detected at varying concentrations of anti-SR revealed that particle dimensions were fairly uniform at a variety of low concentrations of anti-SR, but the diameters increased at higher concentrations. Figure $1 \mathrm{~B}$ shows a frequency histogram of particle diameters taken from single sections of nuclei stained with 1:5 and 1:25 dilutions of anti-SR hybridoma supernatant. We analyzed single optical sections to avoid the fortuitous overlap of particles present in unrelated sections. Although all of the particles had diameters $<0.5 \mu \mathrm{m}$ in the more dilute case, diameters of up to $1.5 \mu \mathrm{m}$ were detected in the nucleus stained with the 1:5 dilution. The smaller population of particles was present in both samples, but the detection of a number of the larger objects resulted in the skewing of the average diameter of the particles and much larger standard deviations (Table 1). At low concentrations average diameters were identical, suggesting that these are the units of SR protein localization (Table $1 ; 1: 100$ and 1:25). Note that the diameters presented here are an underestimate of particle size, because three-dimensional reconstructions of multiple interphase nuclei stained with low concentrations of anti-SR $(1: 10)$ revealed an average diameter of $0.31 \pm 0.20 \mu \mathrm{m}(n=974$ particles $)$, slightly larger than the optical section size $(0.2 \mu \mathrm{m})$. Each nucleus contained an average of $244 \pm 25$ particles ( $n=4$ nuclei). We hypothesize that these particles represent the sites of highest concentration of SR proteins in the HeLa cell nucleus. 

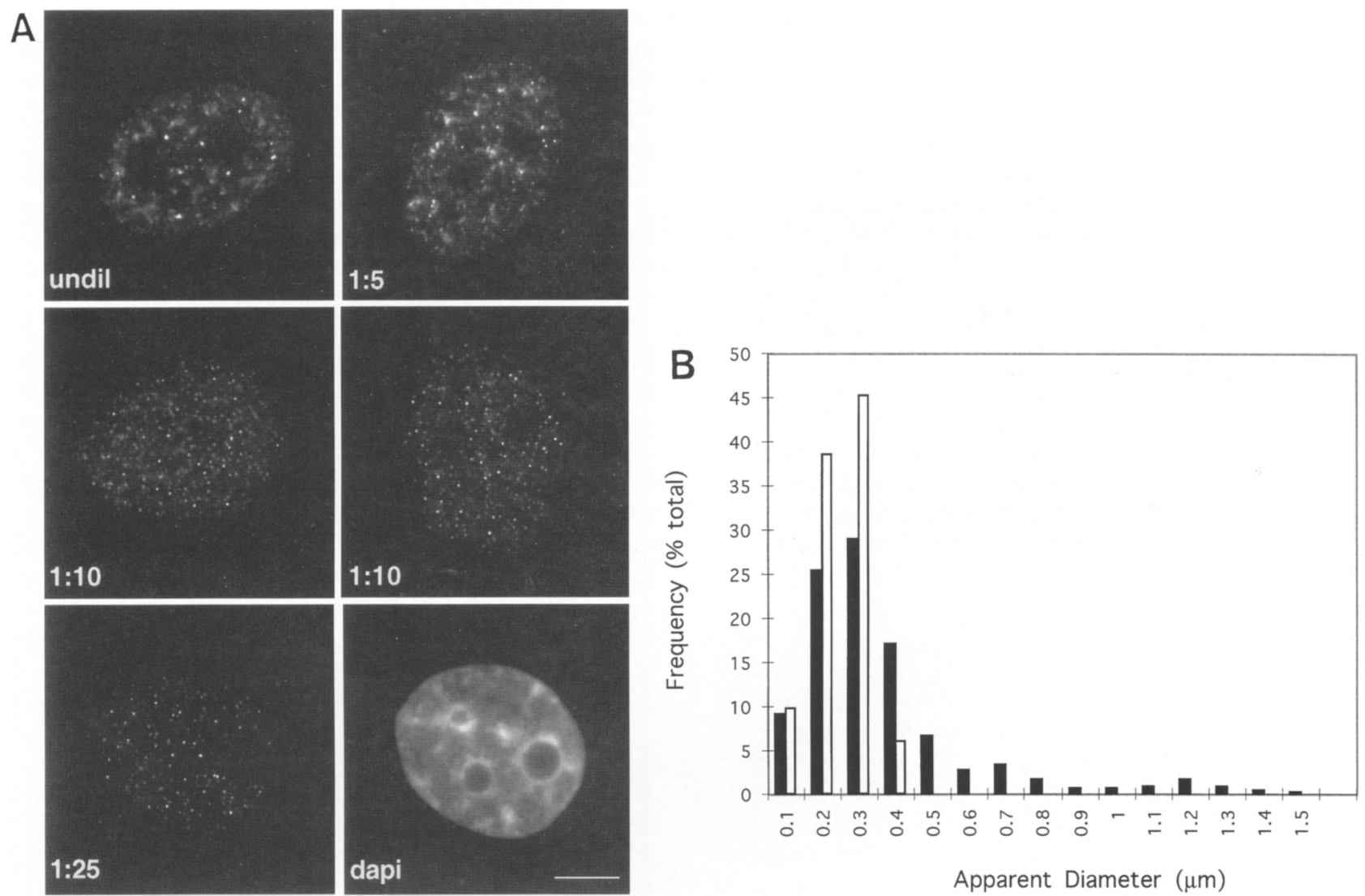

Figure 1. Detection of SR proteins in particles distributed throughout the HeLa cell nucleoplasm. $(A)$ Detection of SR proteins in nuclei exposed to different concentrations of anti-SR in the staining experiment. Anti-SR was used at the indicated dilutions of the hybridoma supernatant, containing $\sim 10 \mu \mathrm{g} / \mathrm{ml}$ of IgG. (undil) Undiluted hybridoma supernatant. Note the appearance of much larger staining objects with increasing antibody concentration. Three-dimensional reconstructions of the entire nuclei were projected. These cells were fixed with acetone at $-20^{\circ} \mathrm{C}$, as described. Scale bar, $4 \mu \mathrm{m}$. $(B)$ Frequency histogram of particle diameters determined in individual 0.2- $\mu \mathrm{m}$ optical sections from nuclei stained with 1:5 anti-SR (回) or 1:25 anti-SR ( $\square$ ).

The observation that antibody concentration can influence nuclear morphology as detected by indirect immunocytochemistry prompted us to determine whether a similar phenomenon occurs when other antibodies are used to examine nuclear structure. Another $\mathrm{mAb}$ with specificity for SR proteins, $\alpha$ SC-35, has been used extensively in analyzing nuclear speckles (Fu and Maniatis 1990; Spector et al. 1991). Figure 2A shows that dilution of $\alpha \mathrm{SC} 35$ also results in the detection of particles rather than speckles. Similar results were obtained with the anti-SR mAb 104 following 10-fold dilution (data not shown). Note that even though the concentration of $\alpha \mathrm{SC}-35$ in hybridoma supernatant is not significantly higher than anti-SR or mAb 104, it must be diluted much further to eliminate the detection of the speckled network. Thus, it seems that the working concentrations of any antibody used for immunocytochemistry should be determined empirically.

If the particles are substructures of speckles, then there should be a spatial correlation between the occurrence of particles and speckles. To address this possibility, we sequentially stained nuclei first with low, and
Table 1. Size of anti-SR-reactive particles: dependence on antibody concentration

\begin{tabular}{lccc}
\hline Antibody & Number $^{\mathrm{a}}$ & $\begin{array}{c}\text { Avg. diam. } \\
(\mu \mathrm{m})^{\mathrm{b}}\end{array}$ & $\begin{array}{c}\text { Maximum } \\
(\mu \mathrm{mm})^{\mathrm{c}}\end{array}$ \\
\hline anti-SR (1:100) & 688 & $0.20 \pm 0.08$ & 0.41 \\
anti-SR (1:25) & 947 & $0.19 \pm 0.07$ & 0.36 \\
anti-SR (1:10) & 730 & $0.32 \pm 0.19$ & 1.18 \\
anti-SR (1:5) & 345 & $0.31 \pm 0.24$ & 1.41 \\
anti-SR (undil.) & 396 & $0.33 \pm 0.22$ & 1.25 \\
anti-SRp20 (undil.) & 125 & $0.19 \pm 0.07$ & 0.30 \\
\hline
\end{tabular}

To assess the effect of primary antibody concentration on the size of particles detected, indirect immunofluorescence was performed with varying dilutions of hybridoma cell supernatant as indicated. The size and number of particles in multiple $0.2-\mu \mathrm{m}$ sections were measured using NIH Image. Note that because the depth of each section is less than the average apparent diameter of the particles $(\sim 0.3 \mu \mathrm{m}$; see text), the average diameter shown here is an underestimate of the particle diameter.

${ }^{a}$ The total number of determinations per data set.

${ }^{\mathrm{b}}$ The average diameter represents the mean and standard deviation. ${ }^{\mathrm{c}}$ Maximum refers to the largest particle detected in the population. 

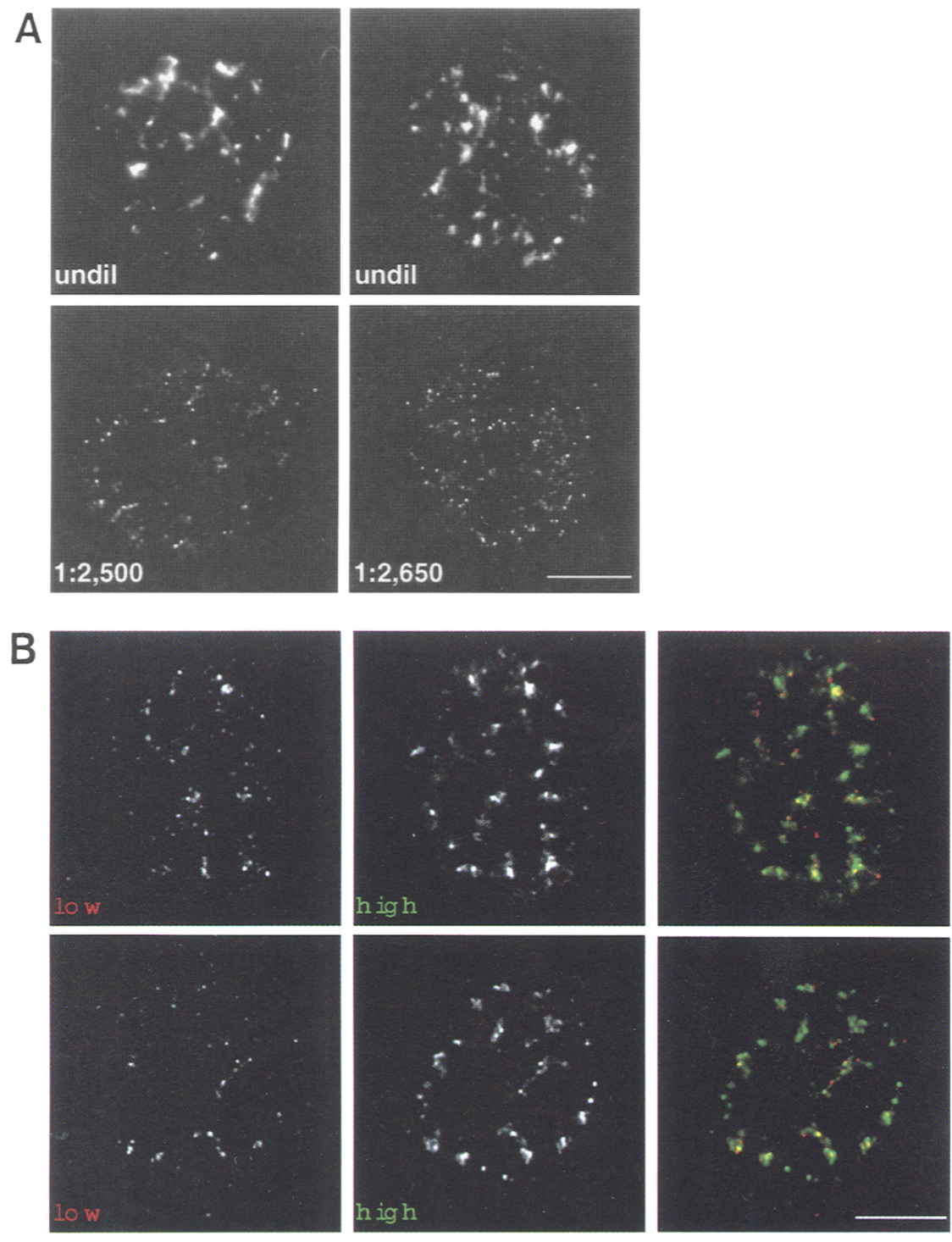

Figure 2. $(A)$ Detection of SR proteins in HeLa cell nuclei with $\alpha$ SC-35 undiluted or diluted, as indicated. $(B)$ Sequential detection of particles and speckles with $\alpha$ SC-35. Nuclei were first stained with $0.005 \mu \mathrm{g} / \mathrm{ml}$ of $\alpha \mathrm{SC}-35$ followed by a RITC-conjugated secondary antibody (low, red), then restained with $0.050 \mu \mathrm{g} / \mathrm{ml}$ of $\alpha \mathrm{SC}-35$, followed by a FITC-conjugated secondary antibody (high, green). Single optical sections through two representative nuclei are shown. In both experiments, the cells were fixed with acetone at $-20^{\circ} \mathrm{C}$. Scale bar, $4 \mu \mathrm{m}$.

then, with high concentrations of $\alpha \mathrm{SC}-35$, using two different fluorochromes with which to visualize particles and speckles. Nuclei were examined following the first staining step, and the coverslips were marked such that the same nuclei could be located and examined following the second staining step. Figure 2B shows single optical sections of two representative nuclei following the second staining procedure. Particles detected with 0.005 $\mu \mathrm{g} / \mathrm{ml}$ of purified $\alpha \mathrm{SC}-35 \mathrm{IgG}$ are shown in red; particles and speckles detected with $0.05 \mu \mathrm{g} / \mathrm{ml}$ of $\alpha \mathrm{SC}-35 \mathrm{IgG}$ are shown in green. The particles detected with the low concentration of $\alpha \mathrm{SC}-35$ occurred throughout the nucleoplasm and did not appear to be confined to regions subsequently bound by high concentrations of $\alpha \mathrm{SC}-35$. There were examples of (1) particles where no speckle was subsequently detected, (2) speckles where no particles were detected, and (3) particles within speckles that did not coincide with the brightest or largest portion of the speckle (Fig. 2B). The average diameter of the par- ticles did not change significantly upon restaining with the high concentration of $\alpha \mathrm{SC}-35$, and the positions of the particles were also unchanged (data not shown). Because $\alpha \mathrm{SC}-35$ used at high concentration has been shown previously to react with interchromatin granules (Spector et al. 1991), the results suggest that the particles detected by either $\alpha \mathrm{SC}-35$ or anti-SR exist both in and out of interchromatin granules. A possible explanation for the differences in the staining patterns observed is that the particles that are always detectable (see Fig. 1B) represent the highest concentrations of SR proteins in the nucleus, whereas interchromatin granules or speckles contain lower concentrations.

Another set of antigens detected in speckles are the nucleoplasmic Sm antigens, which are core components of snRNPs that function in pre-mRNA splicing (Spector 1990). Figure 3 shows that a concentration of the anti-Sm mAb Y12 typically used in previous work detects three types of nuclear objects: speckles, smaller particles, and 

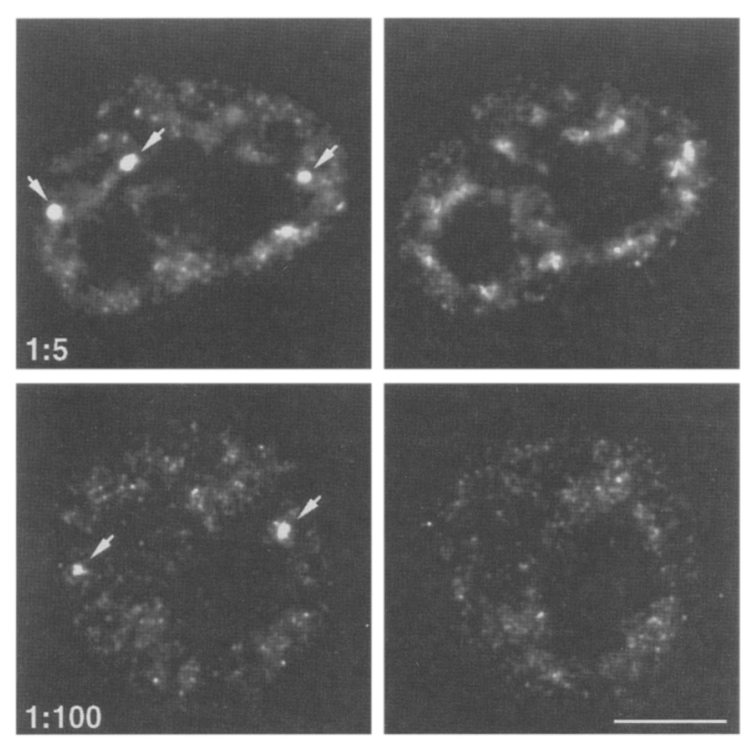

Figure 3. Dilution of the anti-Sm mAb Y 12 results in punctate staining of the nucleoplasm rather than speckles, whereas the coiled bodies are detected at all concentrations tested. Two optical sections of each of two cells stained with Y12 diluted 1:5 or 1:100, respectively, are shown. The sections shown in the left-hand panels contain coiled bodies (arrowheads); the coiled bodies are not present in the sections in the right-hand panels. These cells were fixed with acetone at $-20^{\circ} \mathrm{C}$ as described. Scale bar, $4 \mu \mathrm{m}$.

coiled bodies (Lerner et al. 1981; Petterson et al. 1984; Carmo-Fonseca et al. 1991). Nuclei stained with a 20 fold dilution of Y12 contained coiled bodies and small particles, but speckles were not apparent. Similar results were obtained with a human anti-Sm antiserum (Kung) and $\mathrm{a} \mathrm{mAb}$ specific for the trimethylguanosine cap of snRNAs (data not shown). Therefore, it appears that dilution of the detecting antibodies permits higher resolu- tion of nucleoplasmic particles, presumably the highest concentration of antigens.

Because the speckles described previously do not often coincide with sites of transcription and pre-mRNA splicing (Wansink et al. 1993; Zhang et al. 1994), we wanted to determine whether these new sites of anti-SR recognition, the discrete particles, overlapped with sites of transcription. Therefore, we compared the distribution of SR proteins with the location of newly synthesized RNA. Bromo-UTP (BrUTP) was incorporated into RNA in a nuclear run-on experiment and then detected using a rat $\mathrm{mAb}$ against $\mathrm{BrU}$ (Wansink et al. 1993). Similar to the results of others (Jackson et al. 1993; Wansink et al. 1993), several hundred foci of BrUTP were detected following a 30 minute run-on procedure (Fig. 4a). RNA Pol II transcription proceeds slowly $(-30$ nucleotides per minute) under these conditions, and diffusion of labeled transcripts away from sites of BrUTP incorporation has not been detected (Darnell 1982; Jackson et al. 1993; Wansink et al. 1993; Iborra et al. 1996). Therefore, labeled transcripts of a maximum of -1000 nucleotides will have been synthesized during the run-on, suggesting that these foci represent multiple nascent RNAs at active sites of transcription. The localization of RNA Pol II to these same sites supports this interpretation (Iborra et al. 1996; K. Neugebauer and M. Roth, unpubl.). Because rates of pre-mRNA splicing have been estimated at 3-30 min in intact nuclei (Darnell 1982), it is likely that many of these nascent RNAs may undergo splicing and/or spliceosome assembly during the course of the experiment. Double-staining of these nuclei with anti-SR reveals that a significant fraction of the particles reactive with antiSR overlap in three-dimensional space with sites of BrUTP incorporation (Fig. $4 \mathrm{c}, \mathrm{f}$ ).

Statistical analysis of the overlap between anti-SR staining and BrUTP incorporation was performed on sets of $0.6-\mu \mathrm{m}$ optical sections to avoid the fortuitous overlap of objects in unrelated optical sections (see Materials and

\begin{abstract}
Figure 4. Detection of SR proteins at sites of BrUTP incorporation. Doublestaining of HeLa cells following run-on transcription in the presence of BrUTP with rat anti-BrU $(a, d)$ and anti-SR diluted $1: 10\langle b, e\rangle$. The two images were multiplied together in Adobe Photoshop to create another channel $(c, f)$ to reveal only those particles containing both signals. High-magnification images $(d-f)$ show that many of the overlapping particles appear identical in three-dimensional space (arrows). The lowest arrow points to a particle recognized by anti-SR that overlaps a differently shaped object detected by anti-BrUTP. Following run-on transcription, cells were fixed with formaldehyde as described in Materials and Methods. Scale bars, $(a-c) 4$ $\mu \mathrm{m} ;(d-f) 1 \mu \mathrm{m}$.
\end{abstract}
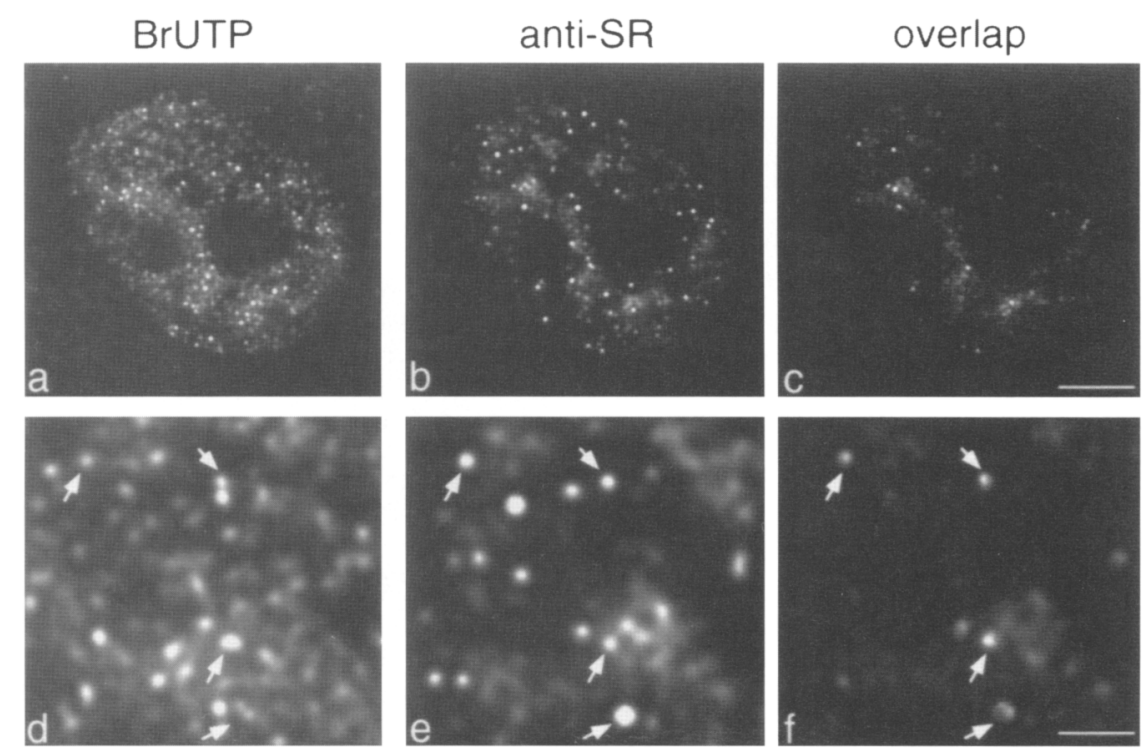
Methods; footnote to Table 2). Five nuclei were analyzed in this manner, and the results are summarized in Table $2 \mathrm{~A}$. The fraction of anti-SR-reactive particles that contained detectable amounts of BrUTP varied from $22 \%$ to $55 \%$ from section to section. On average, BrUTP incorporation was detectable in $35.0 \% \pm 13.8 \%$ of the SRpositive particles. This degree of overlap differed significantly from that expected if particles overlapped by random chance (see Table 2A and footnote). Therefore, we conclude that at these levels of detection we were able to visualize the accumulation of SR proteins at sites of RNA Pol II transcription.

Knowing the overall distribution of the family of SR proteins, we wondered whether a single SR protein species would be distributed similarly. A new $\mathrm{mAb}$, antiSRp20, was raised against a peptide immunogen derived from the sequence of human SRp20. Whereas $\alpha \mathrm{SC}-35$ (Fig. 5A, lane 1) and anti-SR (Fig. 5A, lane 3) bind all of the members of the SR protein family, anti-SRp20 is absolutely specific for SRp20 among purified SR proteins (Fig. 5A, lane 5) and highly specific for SRp20 in an immunoblot of HeLa cell nuclear extract (Fig. 5A, lane 6). Anti-SRp20 was not dependent on the phosphorylation of SRp20 in contrast to anti-SR, which binds a phosphate-dependent epitope (data not shown); this difference may explain why anti-SRp20 is more sensitive than either anti-SR or $\alpha \mathrm{SC}-35$ for detecting antigens in Western blots of whole cell or nuclear extracts (cf. lane 6 with lanes 2 and 4).

Immunostaining experiments with the anti-SRp20 $\mathrm{mAb}$ revealed $47 \pm 2$ particles per HeLa cell nucleus ( $n=3$ nuclei), only one-fifth the number of nucleoplas-

Table 2. Quantitative analysis of the number of anti-SR, anti-SRp20, and anti-BrUTP-positive particles in projected $0.6 \mu \mathrm{m}$ sections of three-dimensional reconstructions

\begin{tabular}{|c|c|c|c|c|c|c|}
\hline \multirow[b]{2}{*}{ Nucleus } & \multicolumn{5}{|c|}{ A. Degree of overlap between $S R$ proteins and BrUTP incorporation } & \multirow[b]{2}{*}{$\%$ SR with BrUTF } \\
\hline & Area $\left(\mu \mathrm{m}^{2}\right)$ & No. SR & No. BrUTP & No. overlap & $\begin{array}{l}\text { Observed } \\
\text { no. overlap }\end{array}$ & \\
\hline la & 223 & 189 & 152 & $8 \pm 3$ & 62 & 33 \\
\hline $1 \mathrm{~b}$ & 242 & 182 & 106 & $5 \pm 2$ & 41 & 23 \\
\hline 2 & 315 & 77 & 164 & $2 \pm 1$ & 42 & 55 \\
\hline 3 & 268 & 43 & 100 & $1 \pm 1$ & 13 & 30 \\
\hline Average & & & & & & $35 \pm 14$ \\
\hline
\end{tabular}

B. Degree of overlap between SRp20 and BrUTP incorporation

\begin{tabular}{lcccccc} 
Nucleus & Area $\left\{\mathrm{\mu m}^{2}\right\rangle$ & No. SRp20 & No. BrUTP & $\begin{array}{c}\text { Expected } \\
\text { no. overlap }\end{array}$ & $\begin{array}{c}\text { Observed } \\
\text { no. overlap }\end{array}$ & \% SR with BrUTP \\
\hline 4 & 270 & 29 & 91 & $1 \pm 1$ & 17 & 59 \\
$5 \mathrm{a}$ & 425 & 55 & 82 & $1 \pm 1$ & 16 & 29 \\
$5 \mathrm{~b}$ & 458 & 76 & 256 & $3 \pm 1$ & 30 & 40 \\
6 & 395 & 11 & 26 & $<1$ & 2 & 18 \\
7 (2) nuclei $)$ & 581 & 41 & 256 & $1 \pm 1$ & 18 & 44 \\
$\quad$ Average & & & & & & $38 \pm 15$
\end{tabular}

These data sets accommodate complete particles, the diameters of which are greater than the depth of the optical sections collected $(0.2 \mu \mathrm{m})$, without generating fortuitous overlap in unrelated sections. The number of reactive particles was determined using NIH Image. The number (no.) of particles reactive with both anti-SR and BrUTP $(A)$ or anti-SRp20 $(B)$ and BrUTP was determined by multiplying the two signals together to create a distinct channel; any particle reactive with only one of the probes is not represented in this channel. These data are shown as no. overlap and were divided by no. anti-SR $(A)$ or no. anti-SRp20 $(B)$ to generate the \% SR with BrUTP. The average show the mean and standard deviation for the data shown.

Statistical significance. The number of particles reactive with both anti-SR/SRp20 and anti-BrU that would be expected by random chance (expected no. overlap) was calculated based on a prediction that accounts for the surface area of the nuclear projection analyzed [area $\left.\left(\mu \mathrm{m}^{2}\right)\right]$, the size and number of the anti-SR/SRp20 particles, and the number of the particles containing BrUTP. The average surface area of each type of particle was $0.06 \pm 0.01 \mu^{2}$ for the anti-SR/SRp20 particles, $0.04 \pm 0.01 \mu \mathrm{m}^{2}$ for the anti-BrUTP particles, and $0.03 \pm 0.01 \mathrm{\mu m}^{2}$ for the particles present in the overlapping channel. The fact that the latter particles are of indistinguishable dimension from the BrUTP-positive particles suggests that the centers of the two overlapping particles must be very close. To predict Expected no. of overlap, we multiplied the fraction of the nucleus occupied by anti-SR signal-[number (SR particles) $\times$ surface area [SR particles)]/nuclear surface area-by the number of BrUTP-positive particles. This is a very conservative prediction, because (1) it allows the differently colored particles to overlap anywhere within their surface area, even though we know that the majority of the overlapping signals are well-centered (see above, and Figs. 4 and 6), (2) the BrUTP-positive particles are slightly smaller than the SR-positive particles, and (3) we inspected many of the particles within the $0.2-\mu \mathrm{m}$ optical sections to confirm that the projected particles from the thicker $0.6-\mu \mathrm{m}$ sections overlapped in three-dimensional space. Had we calculated the expected number of particles based on volume rather than surface area, a four-fold smaller number would have been predicted. Despite these conservative calculations, the probability of measuring the Observed no. overlap $(p)$ was in every case $<10^{-4}$ (nucleus $1 \mathrm{a}, p<10^{-34}$; nucleus $1 \mathrm{~b}, p<10^{-24}$; nucleus $2, p<10^{-37}$; nucleus $3, p<10^{-11}$; nucleus $4, p<10^{-19}$; nucleus $5 \mathrm{a}, p<10^{-18}$; nucleus $5 \mathrm{~b}, p<10^{-22}$; nucleus $6, p<10^{-4}$; nucleus $7, p<10^{-16}$ ) (see Materials and methods.) 

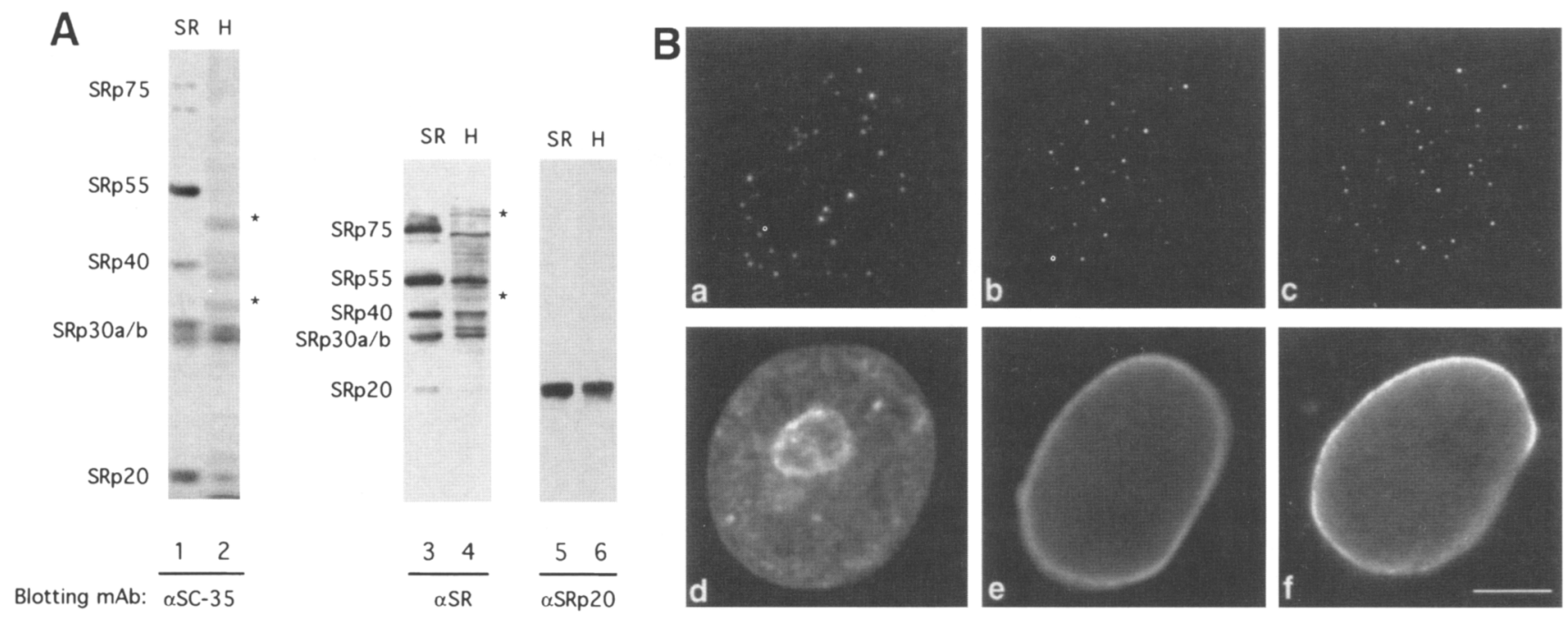

Figure 5. Characterization of mAb anti-SRp20. (A) $\alpha \mathrm{SC}-35$ and anti-SR bind all of the canonical members of the SR protein family (lanes 1 and 3, respectively). Anti-SRp20 is absolutely specific for SRp20 among purified SR proteins (lane 5) and highly specific for SRp20 in HeLa nuclear extract (lane 6). Lanes in which purified SR proteins were loaded are labeled SR; lanes containing $100 \mu \mathrm{g}$ of HeLa cell extract (lane 2) or HeLa cell nuclear extract (lanes 4,6) are labeled $H$. The positions of the canonical SR proteins are indicated. Note that SRp75 has run as a doublet in lane 1 as a result of partial degradation. Because anti-SR and $\alpha$ SC-35 are less sensitive in Western blots than anti-SRp20, the former blots were developed more extensively, leading to the appearance of bands detected in the absence of primary antibody. These are considered background and are indicated with asterisks. $(B)$ Three examples of anti-SRp20 staining of interphase HeLa cell nuclei. Anti-SRp20 hybridoma supernatant was used undiluted. Three-dimensional reconstructions of the entire nuclei were projected $(a-c)$. To delineate the borders of the nuclei, corresponding images of DAPI staining are shown $(d-f)$. Because the latter images were processed differently, they vary in the amount of detail. These cells were fixed with acetone at $-20^{\circ} \mathrm{C}$ as described. Scale bar, $4 \mu \mathrm{m}$.

mic particles detected by anti-SR. Thus, although SRp20 comprises only a small fraction of total HeLa cell SR proteins $(-2.5 \%$; Zahler et al. $1993 \mathrm{~b})$, it is readily detectable in interphase nuclei stained with undiluted $(\sim 10 \mu \mathrm{g} /$ $\mathrm{ml}$ ) anti-SRp20 hybridoma supernatant (Fig. 5B). Like the particles seen with anti-SR, particles detected by antiSRp20 averaged $0.24 \pm 0.11 \mu \mathrm{m}$ in diameter $(n=144$ particles) and were not interconnected. In addition, the average diameter of these particles in single optical sections was also identical to that of the smaller species of particles recognized by anti-SR (Table 1). It is interesting that anti-SRp20 did not detect more numerous particles or larger aggregates at any concentration, even upon purification and concentration of the IgG (data not shown). To determine whether BrUTP can be incorporated at sites of anti-SRp20 recognition, anti-SRp20 was used in double-staining experiments following nuclear runon (see above). Figure 6 shows that particles reactive with anti-SRp20 do react with anti-BrU. Indeed, $37.9 \% \pm 15.3 \%$ of anti-SRp20 reactive particles were positive for BrUTP incorporation (Table 2B), a similar proportion as compared with BrUTP-positive anti-SR reactive particles. These data indicate that we are able to detect a single species of SR protein, SRp20, at sites of RNA Pol II transcription.

The difference in the numbers of particles detected with the two antibodies against SR proteins suggested that SRp20 is present at high concentrations at only a subset of the locations of high SR protein concentration.
To address this possibility, double indirect immunofluorescent staining experiments were performed. Figure 7 shows an example of a HeLa cell nucleus first stained with anti-SRp20 followed by a RITC-conjugated secondary antibody and subsequently with anti-SR followed by a FITC-conjugated secondary antibody. These nuclei contain a small number of particles detected with anti-SRp20 and many more detected with anti-SR (Fig. $7 a, b$ ). In the image generated by merging the two wavelengths, all of the particles reactive with anti-SRp20 are also reactive with anti-SR (Fig. $7 \mathrm{~d}, \mathrm{f}$, arrows). However, many of the particles reactive with anti-SR do not contain detectable amounts of SRp20 (Fig. $7 \mathrm{e}, \mathrm{f}$, arrows). Note that a range of labeling intensities is observed for particles recognized by anti-SR and anti-SRp20. Based on the number of SR and SRp20 particles determined independently from single-staining experiments (see above), we would expect $\sim 20 \%$ of the particles detected with anti-SR to contain SRp20. Analysis of six double-stained nuclei reveals that $27.3 \% \pm 8.7 \%$ of the particles reactive with anti-SR were also labeled with anti-SRp20. Thus, members of the SR protein family appear to be distributed heterogeneously among the sites of highest concentration of SR proteins in the nucleus. Because these sites often coincide with sites of accumulation of recently synthesized RNA Pol II transcripts, we suggest that individual SR proteins may be differentially recruited to the sites of synthesis of particular pre-mRNAs. 

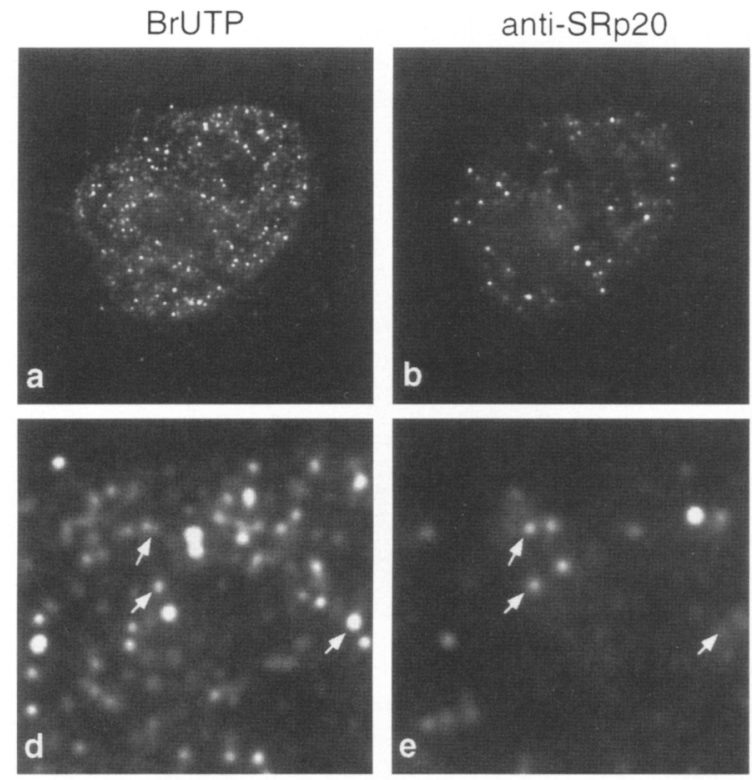

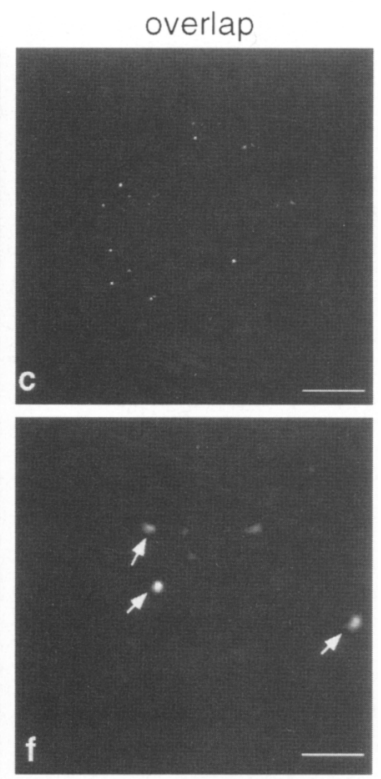

Figure 6. Detection of $\operatorname{SRp} 20$ at sites of BrUTP incorporation. Double-staining of HeLa cells following run-on transcription in the presence of BrUTP with rat anti-BrU $\{a, d)$ and anti-SRp20 $(b, e)$. The two images were multiplied together in Adobe Photoshop to create another channel $(c, f)$ to reveal only those particles containing both signals. High-magnification images $(d-f)$ show that many of the overlapping particles appear identical in three-dimensional space (arrows). Following run-on transcription, cells were fixed with formaldehyde as described in Materials and Methods. Scale bars, $(a-c) 4 \mu \mathrm{m} ;(d-f) 1 \mu \mathrm{m}$.

\section{Discussion}

The results presented here support three major conclusions. First, SR proteins and snRNPs are detectable in hundreds of small nuclear particles distinct from the larger, interconnected structures known as speckles. Based on a titration of the antibodies (Y12, anti-SR, $\alpha$ SC35 , and $\mathrm{mAb} 104$ ) used for detection, we interpret these particles to represent the highest concentrations of splicing factors in HeLa cells. Second, the anti-SR-reactive particles frequently coincide with sites of RNA Pol II transcription, where pre-mRNA splicing likely occurs; $-35 \%$ of these particles contained detectable BrUTP following run-on transcription. Finally, high concentrations of one SR protein, SRp20, were detected at fewer sites, and these also overlapped with transcription. The restricted distribution of SRp20 indicates that individual SR proteins may be concentrated at the sites of transcription of particular, endogenous target genes.

In intact nuclei, splicing factors have been localized
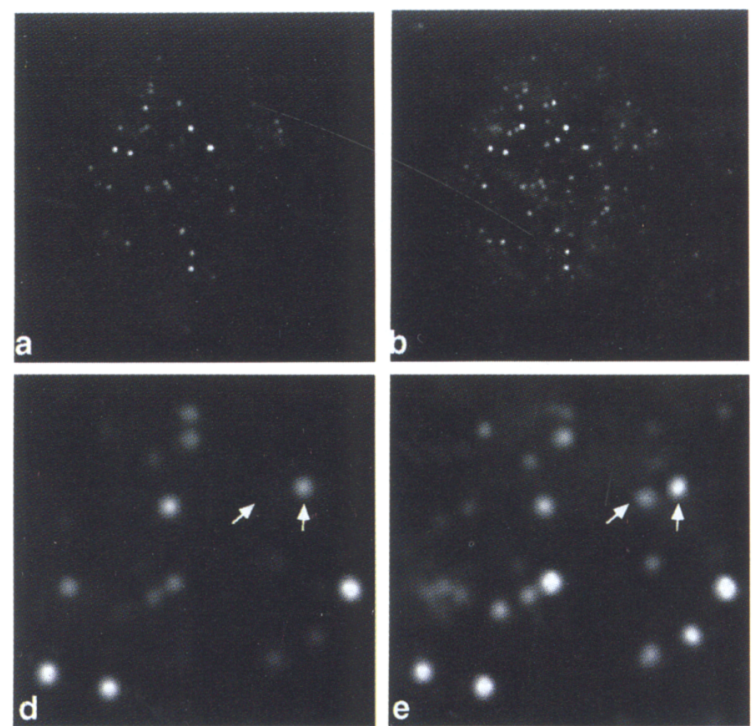

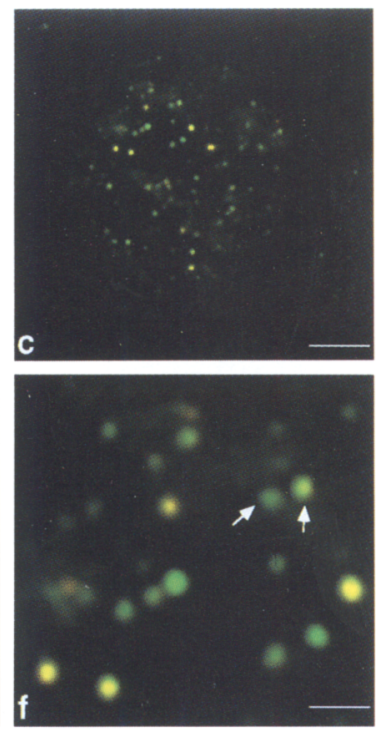

Figure 7. SRp20 is detectable at only a subset of sites of SR protein localization. Anti-SRp20 $(a, d)$ recognizes a smaller number of particles than anti-SR $\{b, e\}$. In $c$ and $f$, the two channels have been merged and are shown in color. Anti-SRp20 was detected with a RITC-conjugated secondary antibody; however, all of these particles are also bound by the FITC-conjugated antibody used to detect anti-SR. Therefore, SRp20-positive particles are yellow, whereas particles detected by antiSR only appear green. Note that the FITCconjugated secondary antibody also recognizes the first primary antibody, antiSRp20; therefore, the apparent coincidence of the brightest green and red particles should not necessarily be attributed to a high concentration of SR proteins in these particles in general. Arrows indicate examples of the two types of particles; the left arrow points to an object containing only anti-SR; the particle to its right reacts with both probes. In this experiment, the cells were unfixed and permeabilized with Triton X-100 in CSK buffer. Scale bars, $(a-$ c) $4 \mu \mathrm{m} ;\langle d-f), 1 \mu \mathrm{m}$. 
primarily to 20-50 large speckles, highly interconnected objects that do not coincide in three-dimensional space with the unrestricted nucleoplasmic distribution of transcription and pre-mRNA splicing, though some genes occur in or near the periphery of speckles (Wansink et al. 1993; Fakan 1994; Zhang et al. 1994; Xing et al. 1995). Speckles are thought to correspond to interchromatin granules, electron-dense regions of the nucleus that are not major sites of cellular transcription (Spector et al. 1991; Fakan 1994; Mattaj 1994). Instead, perichromatin fibrils are the electron microscopic structures that appear to correspond with sites of transcription and splicing, but these have only been associated with low levels of SR proteins and snRNPs (Fakan 1994). By immunofluorescent light microscopy, speckles are detectable with a number of monoclonal antibodies, notably $\alpha \mathrm{SC}-35$ and $3 \mathrm{C} 5$, which recognize all members of the SR protein family (Fu and Maniatis 1990; Spector et al. 1991; Bridge et al. 1995; for $\alpha$ SC-35 see Fig. 5A), antibodies specific for the Sm epitope common to snRNPs (eg., Y12; Petterson et al. 1984; Spector 1990), and oligonucleotide probes for the U1 and U2 snRNAs (Carmo-Fonseca et al. 1991, 1992; Huang and Spector 1992). When typical concentrations $(-2-10 \mu \mathrm{g} / \mathrm{ml})$ of anti-SR were used in the staining experiment, large objects $(>1 \mu \mathrm{m})$ resembling speckles were also visualized. However, dilution of anti-SR resulted in the detection of a more homogeneous population of hundreds of smaller $(-300 \mathrm{~nm})$ particles distributed throughout the nucleoplasm (see Fig. 1; Table 1). Dilution of $\alpha \mathrm{SC}-35$ and Y12 similarly eliminated the population of larger objects, whereas smaller particles remained (Figs. 2A and 3). By double-staining nuclei with first low and then high concentrations of $\alpha \mathrm{SC}-35$, we found that the particles were detected within as well as outside of the speckles. This experiment suggests that the particles contain the highest concentrations of SR proteins in the nucleus, whereas speckles may contain less. The fact that particles are detectable at high as well as low antibody concentrations (see Fig. $1 \mathrm{~B}$ ) is consistent with this interpretation. Interestingly, speckles are not detectable with anti-SRp20, suggesting that SRp20 may not be present in speckles.

Our results indicate that the highest concentrations of SR proteins in the nucleus often coincide with active sites of transcription. At the present limits of detection, $-35 \%$ of the particles recognized by anti-SR also stained with a mAb against BrU following a nuclear run-on procedure in which BrUTP was incorporated into newly synthesized transcripts. A similar percentage $(-37 \%)$ of the particles recognized by the anti-SRp $20 \mathrm{mAb}$ also contain BrUTP in a parallel experiment. It is possible that a higher proportion of the particles detected by anti-SR are present at active sites of transcription, but the detection of BrUTP incorporation may be limited. It is also possible that some of the particles are not associated with an active pre-mRNA splicing function. For example, Alzhanova-Ericsson and colleagues (1996) have suggested that SR proteins may participate in other events during RNA export from the nucleus. Conversely, the SR-negative sites of BrUTP incorporation may contain levels of SR proteins that are below our levels of detection. In future studies it will be of interest to determine whether SR proteins are absent where intronless pre-mRNAs are transcribed, as this may also account for some of the SR-negative sites. In addition, although BrUTP does not significantly slow the transcription rate, high levels of BrUTP incorporation inhibit splicing (Wansink et al. 1993, 1994); thus, this detection method may itself reduce the accumulation of splicing factors on RNA. For all of these reasons, we do not wish to attribute too great a significance to the fact that sites of BrUTP incorporation and anti-SR reactivity do not always appear to coincide. Instead, the very significant overlap between sites of anti-SR reactivity and BrUTP incorporation suggests that SR proteins specifically accumulate on endogenous pre-mRNAs, consistent with their proposed functions in pre-mRNA splicing.

The observation that SR proteins are concentrated at active sites of transcription in mammalian nuclei indicates that nuclear structure and function is conserved among cells. Where particular cytological methods have been available, splicing factors have been detected at active sites of transcription. On Drosophila polytene chromosomes, SRp55 (B52) and RBP1 (possibly the homolog of SRp20; see Manley and Tacke 1996) were detected at transcriptionally active puffs as well as bands reactive with antibodies against RNA Pol II (Champlin et al. 1991; Kim et al. 1992). Importantly, a range of immunostaining intensities relative to anti-Pol II was observed in both studies, raising the possibility that these two SR proteins accumulate differently on nascent transcripts in this experimental system. Other classes of pre-mRNA processing factors, namely the heterogenous nuclear RNPs (hnRNPs) and snRNPs, have been shown to associate differentially with nascent transcripts on polytene chromosomes and amphibian lampbrush chromosomes (Amero et al. 1992; Matunis et al. 1993; Wu et al. 1993), but the functional significance of these differences is unknown.

The demonstrated ability to visualize splicing regulators at sites of BrUTP incorporation, each likely a small number of transcription units in HeLa cells (Wansink et al. 1993), indicates that our methods may be of sufficient sensitivity and resolution to permit an analysis of distinct gene regulators at particular genes. Therefore, we have examined the distribution of a single species of SR protein, SRp20. A mAb specific for SRp20 was generated and shown to recognize small nucleoplasmic particles like those described above, but never speckles. However, anti-SRp20 recognized many fewer particles than those seen with anti-SR, $47 \pm 2$ per nucleus as compared with $244 \pm 25$. A significant proportion of these particles $(38 \% \pm 15 \%)$ contained BrUTP following run-on transcription, indicating that it is also possible to detect the accumulation of a single SR protein at or very near sites of transcription. Interestingly, double-staining experiments with anti-SR confirm that SRp20 is detectable at only a subset of the SR-positive sites. Anti-SRp20 recognized $27.3 \% \pm 8.7 \%$ of the particles bound by anti-SR, whereas SRp20 was undetectable at the remaining sites 
of high concentration of SR proteins. Thus, the amount of $S R p 20$ relative to the other members of the SR protein family is likely to differ from gene to gene.

Taken together, our data and the previous results of others (cf. Osheim et al. 1985; Kiseleva et al. 1994; Bauren et al. 1996) support a model in which splicing factors accumulate at endogenous sites of transcription where splicing occurs. The detection of a high concentration of any given factor at a gene is likely to depend on the affinity of the factor for the RNA synthesized at the gene. Two lines of evidence suggest that SR proteins bind to RNA in a sequence-specific manner. First, in vitro selection of RNAs that bind to three members of the SR protein family yields three different consensus sequences (Heinrichs and Baker 1995; Tacke and Manley 1995|. Second, exonic splicing enhancers derived from a number of alternatively spliced pre-mRNAs bind distinct SR proteins in vitro (see Black 1995; Manley and Tacke 1996). The approach developed here provides further directions for testing the model that factors accumulate at sites of highest affinity binding. These methods may be generally applicable to studies of gene regulation at the level of single cells, genes, and factors, with the ultimate goal of understanding the relationship between nuclear structure and function.

\section{Materials and methods}

$m A b s$

To generate the mAb against human SRp20, a peptide was synthesized corresponding to amino acids 84-104 (EKRSRNRGPPPSWGRRPRDDY) of the predicted protein that occur between the RNA recognition motif and the SR domain (Ayane et al. 1991; Zahler et al. 1992). Mice bearing the Robertsonian translocation (RBF/DnJ, Jackson Laboratory, Bar Harbor, ME) were immunized with peptide emulsified with complete and subsequently with incomplete Freund's adjuvant (Cappell). Mice were boosted every 2 weeks for 3 months, and test bleeds were taken. The cells of one spleen were fused with Fox-NY hybridoma cells, and hybrids were selected as described in Taggart and Samloff (1983). After 10 days, hybridoma supernatants were tested for reactivity with the SRp20 peptide by ELISA (Harlow and Lane 1988). The anti-SR mAb was generated by immunizing similar mice with mass-isolated nuclei from the oocytes of Xenopus laevis (Tuma et al. 1993). Following fusion, supernatants of selected hybrids were screened by ELISA for reactivity with SR proteins purified from calf thymus (Zahler et al. 1992). Y12 mAb supernatant was the generous gift of Joan Steitz (Yale University, New Haven, CT), and $\alpha \mathrm{SC}-35 \mathrm{mAb}$ supernatant and purified IgG were generously provided by Joseph Gall (Carnegie Institute, Baltimore, MD).

Positive clones were subcloned by serial dilution and tested by immunoblot for their specificity for SR proteins. The clone 7B4A12 is referred to here as anti-SRp20, and the clone 1H4G7 as anti-SR. The concentration of each IgG secreted into the medium and used in immunostaining experiments was estimated at $10 \mu \mathrm{g} / \mathrm{ml}$ based on the recovery of IgG when adsorbed to an affinity resin, such as protein G-Sepharose. Extracts of HeLa cells were prepared by sonication in NEST-2 buffer 150 $\mathrm{mM}$ Tris- $\mathrm{HCl}$ at $\mathrm{pH} 6.8,20 \mathrm{~mm}$ EDTA, 5\% SDS), and human SR proteins were purified from HeLa cells according to Zahler et al. (1992). For immunoblotting, SDS-polyacrylamide gels were transferred to nitrocellulose, stained with Ponceau S, blocked for $10 \mathrm{~min}$ at room temperature in $3 \%$ BSA in TBST $150 \mathrm{~mm}$ Tris- $\mathrm{HCl}$ at $\mathrm{pH} 8.0 ; 150 \mathrm{~mm} \mathrm{NaCl} ; 0.05 \%$ Tween 20 ), and incubated for $1 \mathrm{hr}$ at room temperature in primary antibody. Blots were then washed three times in TBST and processed for colorimetric or ECL (Amersham) detection using the Vectastain $\mathrm{ABC}$ kit (Vector Labs, Burlingame, CA).

\section{Immunostaining procedures}

HeLa cells were grown in DME plus $10 \%$ bovine calf serum (Hyclone) on acid-washed coverslips. Fixation conditions vary as described in the text. When fixed with acetone, coverslips were washed in $\mathrm{Mg}$-PBS (PBS plus $10 \mathrm{~mm} \mathrm{MgCl}_{2}$ ) at $4^{\circ} \mathrm{C}$ and then plunged into acetone-filled wells at $-20^{\circ} \mathrm{C}$ for $2 \mathrm{~min}$. When unfixed, coverslips were washed in CSK buffer minus EDTA (10 mM PIPES at $\mathrm{pH} 6.8,100 \mathrm{~mm} \mathrm{NaCl}, 300 \mathrm{~mm}$ sucrose, $3 \mathrm{~mm}$ $\mathrm{MgCl}_{2}, 1 \mathrm{~mm}$ EGTA) and permeabilized with $0.5 \%$ Triton $\mathrm{X}-100$. Following two washes in $\mathrm{Mg}-\mathrm{PBS}$, coverslips were blocked for $15 \mathrm{~min}$ at room temperature with $5 \%$ normal goat serum in Mg-PBS (Jackson Immunoresearch, West Grove, PA). Coverslips were incubated with primary antibodies for $1 \mathrm{hr}$ at room temperature. Primary antibodies were diluted as indicated in 3\% BSA in Mg-PBS. After three washes in PBS, coverslips were incubated with RITC-conjugated goat anti-mouse IgG (Jackson Immunoresearch). In double-staining experiments, FITC-conjugated goat anti-mouse Fc fragment was also used (Jackson Immunoresearch). Washed coverslips were then mounted in DABCO (Johnson et al. 1982).

Nuclear run-on experiments were performed according to the methods of Wansink et al. (1993). Briefly, coverslips were washed once in TBS, once in glycerol buffer $(20 \mathrm{mM}$ Tris-HCL at $\mathrm{pH} 7.4,5 \mathrm{~mm} \mathrm{MgCl}_{2} ; 25 \%$ glycerol, $0.5 \mathrm{~mm}$ PMSF, $0.5 \mathrm{~mm}$ EGTA), and then permeabilized for $3 \mathrm{~min}$ at room temperature in glycerol buffer plus $0.05 \%$ Triton X-100. Transcription mixture $\left[100 \mathrm{mM} \mathrm{KCl} ; 50 \mathrm{mM}\right.$ Tris- $\mathrm{HCl}$ at $\mathrm{pH} 7.4 ; 5 \mathrm{mM} \mathrm{MgCl}_{2} ; 0.5$ mM EGTA; 25\% glycerol, $25 \mathrm{mM} S$-adenosyl-L-methionine, 1 mM PMSF, $0.5 \mathrm{~mm}$ each of ATP, CTP, and GTP; $0.2 \mathrm{~mm} \mathrm{BrUTP}$ (Sigma) or $0.5 \mathrm{~mm}$ UTP as a control] was added to each coverslip and incubated for $30 \mathrm{~min}$ at room temperature. Cells were fixed by dropping each coverslip into a freshly prepared solution of $4 \%$ EM grade formaldehyde (Polysciences, Warrington, PA) in $\mathrm{Mg}-\mathrm{PBS}$. After fixing for $15 \mathrm{~min}$, coverslips were washed twice with $\mathrm{Mg}-\mathrm{PBS}$ and blocked with $5 \%$ normal goat serum in $\mathrm{Mg}-$ PBS in preparation for staining (see above). To detect sites of BrUTP incorporation, coverslips were incubated for $1 \mathrm{hr}$ with a rat $\mathrm{mAb}$ against $\mathrm{BrU}$ (Sera-Lab, Crawley Down, England) diluted $1: 25$ in 3\% BSA in Mg-PBS; $1 \mathrm{hr}$ with a biotinylated goat anti-rat IgG diluted 1:200 (Jackson Immunoresearch); and 30 min with FITC-conjugated avidin diluted 1:200 (Vector Labs). In doublestaining experiments, these coverslips were then incubated with anti-SR or anti-SRp20 at the indicated dilutions followed by RITC-conjugated goat anti-mouse IgG diluted 1:200 (Jackson Immunoresearch).

\section{Analysis}

Samples were examined by three-dimensional multiple-wavelength fluorescence microscopy using Deltavision (Applied Precision, Mercer Island, WA). Images were collected at the indicated wavelengths for sixteen $0.2-\mu \mathrm{m}$ optical sections per nucleus and were subsequently deconvolved mathematically (Hiraoka et al. 1991; Carrington et al. 1995). The limit of detection (resolution between two points) was 2 voxels, $140 \mathrm{~nm}$ for the $100 \times$ objective and $90 \mathrm{~nm}$ for $100 \times$ with a gain of 1.5 (P. 
Goodwin and C. Brown, pers. comm.). Data were then examined as either optical sections, projections of a small stack of sections, or projections of the entire stack. For all manipulations, light intensity levels were adjusted according to a set of concurrent control experiments in which potential bleed-through from one channel to another or nonspecific binding because of the detecting system was measured. After import into Adobe Photoshop (Adobe Systems, Inc.), threshold levels were selected for the control set that empirically removed all nonspecific and/ or bleed-through signals. These threshold levels were recorded and then applied to the experimental set. To normalize the distribution of intensities for each wavelength, maximum levels were set at one-half of the observed maximum level.

The number and area of fluorescently labeled particles per nucleus was determined from projections of entire stacks of data, using NIH Image (National Institutes of Health, Bethesda, MD). This analysis was performed by applying a threshold intensity limit to produce binary images that could be counted and measured. Note that a shell of the detecting antibodies is likely to add at least $25 \mathrm{~nm}$ to the diameter of each particle (Carrington et al. 1995). Because the average diameter of the particles was larger than the thickness of the optical sections, double-staining experiments were examined as stacks of three sections each. For analysis of the numbers of overlapping particles detected with two distinct probes, channels representing the data from the two wavelengths were multiplied together using Adobe Photoshop to produce a distinct channel representing the location of any overlap between the two channels. For further information regarding this method, see the footnote to Table 2. To ensure that apparent overlap by this method was not a result of fortuitous overlap in the two-dimensional projection of distinct three-dimensional objects, each doubly labeled particle was re-examined in single optical sections. The number of objects in each channel was then quantitated using NIH Image and analyzed using Microsoft Excel.

\section{Acknowledgments}

We gratefully acknowledge the contributions of Paul Goodwin and Tim Knight in greatly assisting with image analysis. We thank Jonathon Howard (University of Washington) for help with the statistical analysis. J. Stark, D. Frank, C. Guthrie, A. Hopper, A. Kirsch, I. Mattaj, M. Morrison, R. Tuma, and J. Valcarcel participated in illuminating discussions and made comments on the manuscript. We thank Applied Precision for the loan of the Deltavision system. K.M.N. was a postdoctoral fellow of the American Cancer Society and the National Multiple Sclerosis Society. This work was supported by NIH grant GM48435-01A2 to M.B.R.

The publication costs of this article were defrayed in part by payment of page charges. This article must therefore be hereby marked "advertisement" in accordance with 18 USC section 1734 solely to indicate this fact.

\section{References}

Alzhanova-Ericsson, A.T., X. Sun, N. Visa, E. Kiseleva, T. Wurtz, and B. Daneholt. 1996. A protein of the SR family of splicing factors binds extensively to exonic Balbiani ring premRNA and accompanies the RNA from the gene to the nuclear pore. Genes \& Dev. 10: 2881-2893.

Amero, S.A., G. Raychaudhuri, C.L. Cass, W.J. van Venrooij, W.J. Habets, A.R. Krainer, and A.L. Beyer. 1992. Independent deposition of heterogeneous nuclear ribonucleoproteins and small nuclear ribonucleoprotein particles at sites of tran- scription. Proc. Natl. Acad. Sci. 89: 8409-8413.

Ayane, M., U. Preuss, G. Kohler, and P.J. Nielson. 1991. A differentially expressed murine RNA encoding a protein with similarities to two types of nucleic acid binding motifs. Nucleic Acids Res. 19: 1273-1278.

Bauren, G., W.-Q. Jiang, K. Bernholm, F. Gu, and L. Wieslander. 1996. Demonstration of a dynamic, transcription-dependent organization of pre-mRNA splicing factors in polytene nuclei. J. Cell Biol. 133: 929-941.

Black, D.L. 1995. Finding splice sites within a wilderness of RNA. RNA 1: 763-771.

Bridge, E., D.-X. Xia, M. Carmo-Fonseca, B. Cardinali, A.I. Lamond, and U. Pettersson. 1995. Dynamic organization of splicing factors in adenovirus-infected cells. J. Virol. 69: 281290.

Caceres, J.F., S. Stamm, D.M. Helfman, and A.R. Krainer. 1994. Regulation of alternative splicing in vivo by over expression of antagonistic splicing factors. Science 265: 1706-1709.

Carmo-Fonseca, M., D. Tollervey, R. Pepperkok, S.M.L. Barabino, A. Merdes, C. Brunner, P.D. Zamore, M.R. Green, E. Hurt, and A.I. Lamond. 1991. Mammalian nuclei contain foci which are highly enriched in components of the premRNA splicing machinery. EMBO J. 10: 195-206.

Carmo-Fonseca, M., R. Pepperkok, M.T. Carvalho, and A.I. Lamond. 1992 Transcription-dependent colocalization of the U1, U2, U4/U6, and U5 snRNPs in coiled bodies. J. Cell Biol. 117: $1-14$.

Carrington, W.A., R.M. Lynch, E.D.W. Moore, G. Isenberg, K.E. Fogarty, and F.S. Fay. 1995. Superresolution three-dimensional images of fluorescence in cells with minimal light exposure. Science 268: 1483-1487.

Champlin, D.T., M. Frasch, H. Saumweber, and J.T. Lis. 1991. Characterization of a Drosophila protein associated with boundaries of transcriptionally active chromatin. Genes \& Dev. 5: 1611-1621.

Darnell, J.E. 1982. Variety in the level of gene control in eucaryotic cells. Nature 297: 365-371.

Fakan, S. 1994. Perichromatin fibrils are in situ forms of nascent transcripts. Trends Cell Biol. 4: 86-90.

Fakan, S., G. Leser, and T.E. Martin. 1984. Ultrastructural distribution of nuclear ribonucleoproteins as visualized by immunocytochemistry on thin sections. I. Cell Biol. 98: 358363.

Fu, X.-D. 1993. Specific commitment of different pre-mRNAs to splicing by single SR proteins. Nature 365: 82-85.

Fu, X.-D. and T. Maniatis. 1990. Factor required for mammalian spliceosome assembly is localized to discrete regions in the nucleus. Nature 343: 437-441.

Harlow, E. and D. Lane. 1988. Antibodies: A laboratory manual. Cold Spring Harbor Laboratory, Cold Spring Harbor, NY.

Heinrichs, V. and B.S. Baker. 1995. The Drosophila SR protein RBP1 contributes to the regulation of doublesex alternative splicing by recognizing RBP1 RNA target sequences. $E M B O$ J. 14: 3987-4000.

Hiraoka, Y., J.R. Swedlow, M.R. Paddy, D.A. Agard, and J.W. Sedat. 1991. Three dimensional multiple-wavelength fluorescence microscopy for the structural analysis of biological phenomena. Semin. Cell Biol. 2: 153-165.

Huang, S. and D.L. Spector. 1992. U1 and U2 small nuclear RNAs are present in nuclear speckles. Proc. Natl. Acad. Sci. 89: $305-308$.

- 1996. Intron-dependent recruitment of pre-mRNA splicing factors to sites of transcription. J. Cell Biol. 133: 719732.

Iborra, F.J., A. Pombo, D.A. Jackson, and P.R. Cook. 1996. Ac- 
tive RNA polymerases are localized within discrete transcription "factories" in human nuclei. J. Cell Sci. 109: 14271436.

Jackson, D.A., A.B. Hassan, R.J. Errington, and P.R. Cook. 1993. Visualization of focal sites of transcription within human nuclei. EMBO J. 12: 1059-1065.

Jimenez-Garcia, L.F. and D.L. Spector. 1993. In vivo evidence that transcription and splicing are coordinated by a recruiting mechanism. Cell 73: 47-59.

Jimenez-Garcia, L.F., M.de L. Segura-Valdez, R.L. Ochs, L.I. Rothblum, R. Hannan, and D.L. Spector. 1994. Nucleologenesis: U3 snRNA-containing prenucleolar bodies move to sites of active pre-rRNA transcription after mitosis. Mol. Biol. Cell 5: 955-966.

Johnson, G.D., R.S. Davidson, K.C. McNamee, G. Russell, D. Goodwin, and E.J. Holborow. 1982. Fading of immunofluorescence during microscopy: A study of the phenomenon and its remedy. I. Immunol. Methods 55: 231-242.

Kim, Y.-J., P. Zuo, J.L. Manley, and B.S. Baker. 1992. The Drosophila RNA-binding protein RBP1 is localized to transcriptionally active sites of chromosomes and shows a functional similarity to human splicing factor ASF/SF2. Genes \& Dev. 6: 2569-2579.

Kiseleva, E., T. Wurtz, N. Visa, and B. Daneholt. 1994. Assembly and disassembly of spliceosomes along a specific premessenger RNP fiber. EMBO J. 13: 6052-6061.

Lerner, E.R., M.R. Lerner, C.A. Janeway, and J.A. Steitz. 1981. Monoclonal antibodies to nucleic acid-containing cellular constituents: Probes for molecular biology and autoimmune disease. Proc. Nat1. Acad. Sci. 78: 2737-2741.

Manley, J.L. and R. Tacke. 1996. SR proteins and splicing control. Genes \& Dev. 10: 1569-1579.

Matera, A.G., K.T. Tycowski, J.A. Steitz, and D.C. Ward. 1994. Organization of small nucleolar ribonucleoproteins (snoRNPs) by fluorescence in situ hybridization and immunocytochemistry. Mol. Biol. Cell 5: 1289-1299.

Matunis, E.L., M.J. Matunis, and G. Dreyfuss. 1993. Association of individual hnRNP proteins and snRNPs with nascent transcripts. J. Cell Biol. 121: 219-228.

Mattaj, I. 1994. Splicing in space. Nature 372: 727-728.

Moore, M.J., C.C. Query, and P.A. Sharp. 1993. Splicing of precursors to mRNA by the spliceosome. In The RNA world led. R.F. Gesteland and A.F. Atkins), pp. 303-357. Cold Spring Harbor Laboratory Press, Cold Spring Harbor, NY.

Osheim, Y.N., O.L. Miller, Jr., and A.L. Beyer. 1985. RNP particles at splice junction sequences on Drosophila chorion transcripts. Cell 43: 143-151.

Penman, S., I. Smith, and E. Holtzman. 1966. Ribosomal RNA synthesis and processing in a particulate site in the HeLa cell nucleus. Science 154: 786-789.

Petterson, I., M. Hinterberger, T. Mimori, E. Gottlieb, and J.A. Steitz. 1984. The structure of mammalian small nuclear ribonuclearproteins. J. Biol. Chem. 259: 5907-5914.

Ramchatesingh, J., A.M. Zahler, K.M. Neugebauer, M.B. Roth, and T.A. Cooper. 1995. A subset of SR proteins activates splicing of the cardiac troponin $\mathrm{T}$ alternative exon by direct interactions with an exonic enhancer. Mol. Cell. Biol. 15: 4898-4907.

Ring, H.Z. and J.T. Lis. 1994. The SR protein B52/SRp55 is essential for Drosophila development. Mol. Cell. Biol. 14: 7499-7506.

Rosbash, M. and R.H. Singer. 1993. RNA travel: Tracks from DNA to cytoplasm. Cell 75: 399-401.

Roth, M.B., C. Murphy, and J. Gall. 1989. A monoclonal antibody that recognizes a phosphorylated epitope stains lampbrush chromosome loops and small granules in the amphib- ian germinal vesicle. J. Cell Biol. 111: 2217-2223.

Roth, M.B., A.M. Zahler, and J.A. Stolk. 1991. A conserved family of nuclear phosphoproteins localized to sites of polymerase II transcription. J. Cell Biol. 115: 587-596.

Spector, D.L. 1990. Higher order nuclear organization: Threedimensional distribution of small nuclear ribonucleoprotein particles. Proc. Natl. Acad. Sci. 87: 147-151.

Spector, D.L., X.-D. Fu, and T. Maniatis. 1991. Associations between distinct pre-mRNA splicing components and the cell nucleus. $E M B O$ J. 10: 3467-3481.

Tacke, R. and J.L. Manley. 1995. The human splicing factors ASF/SF2 and SC35 possess distinct, functionally significant RNA binding specificities. EMBO J. 14: 3540-3551.

Taggart, R.T. and M. Samloff. 1983. Stable antibody-producing murine hybridomas. Science 219: 1228-1230.

Tuma, R., J.A. Stolk, and M.B. Roth. 1993. Identification and characterization of a sphere organelle protein. J. Cell Biol. 122: $767-773$.

Valcarcel, J. and M.R. Green. 1996. The SR protein family: Pleiotropic functions in pre-mRNA splicing. Trends Biochem. Sci. 21: 296-301.

Wansink, D.G., W. Schul, I. van der Kraan, B. van Steensel, R. van Driel, and L. de Jong. 1993. Fluorescent labeling of nascent RNA reveals transcription by RNA polymerase II in domains scattered throughout the nucleus. F. Cell Biol. 122: 283-293.

Wansink, D.G., R.L.H. Neilssen, and L. de Jong. 1994. In vitro splicing of pre-mRNA containing bromouridine. Mol. Biol. Rep. 19: 109-113.

Wu, Z., C. Murphy, H.G. Callan, and J.G. Gall. 1993. Small nuclear ribonucleoproteins and heterogeneous nuclear ribonucleoproteins in the amphibian germinal vesicle: Loops, spheres, and snurposomes. J. Cell Biol. 113: 465-483.

Xing, Y., C.V. Johnson, P.T. Moen, J.A. McNeil, and J.B. Lawrence. 1995. Nonrandom gene organization: Structural arrangements of specific pre-mRNA transcription and splicing within SC-35 domains. J. Cell Biol. 131: 1635-1647.

Zachar, Z., J. Kramer, I.P. Mims, and P.M. Bingham. 1993. Evidence for channeled diffusion of pre-mRNAs during nuclear RNA transport in metazoans. $J$. Cell Biol. 121: 729-742.

Zahler, A.M., W.S. Lane, J.A. Stolk, and M.B. Roth. 1992. SR proteins: A conserved family of pre-mRNA splicing factors. Genes \& Dev. 6: 837-847.

Zahler, A.M., K.M. Neugebauer, W.S. Lane, and M.B. Roth. 1993a. Distinct functions of SR proteins in alternative premRNA splicing. Science 260: 219-222.

Zahler, A.M., K.M. Neugebauer, J.A. Stolk, and M.B. Roth. 1993b. Human SR proteins and isolation of a cDNA encoding SRp75. Mol. Cell. Biol. 13: 4023-4028.

Zhang, G., K.L. Taneja, R.H. Singer, and M.R. Green. 1994. Localization of pre-mRNA splicing in mammalian nuclei. $\mathrm{Na}$ ture 372: 809-812. 


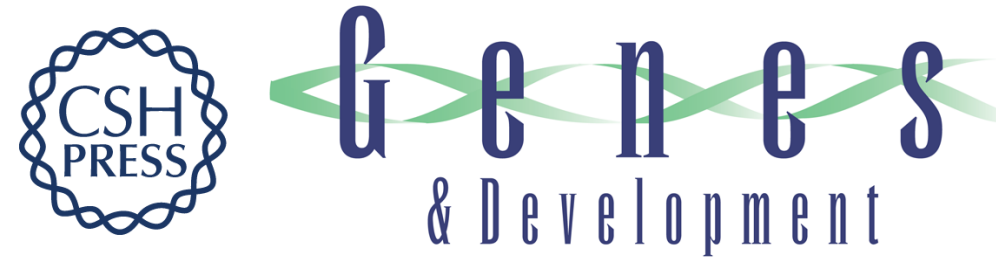

\section{Distribution of pre-mRNA splicing factors at sites of RNA polymerase II transcription.}

K M Neugebauer and M B Roth

Genes Dev. 1997, 11:

Access the most recent version at doi:10.1101/gad.11.9.1148

References This article cites 55 articles, 31 of which can be accessed free at:

http://genesdev.cshlp.org/content/11/9/1148.full.html\#ref-list-1

License

Email Alerting

Service

Receive free email alerts when new articles cite this article - sign up in the box at the top right corner of the article or click here.

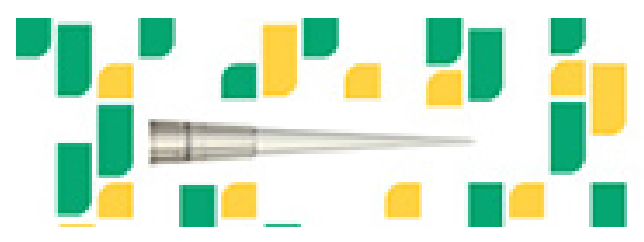

Focused on your science.

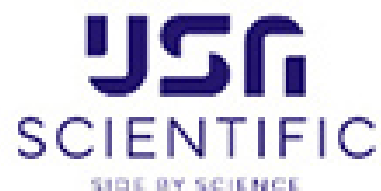

Copyright (c) Cold Spring Harbor Laboratory Press 